(С) А.П. Пестряков, О.М Григорьева, Ю.В. Пеленицына

\title{
КРАНИОЛОГИЧЕСКАЯ ДИФФЕРЕНЦИАЦИЯ БОЛЬШОЙ МОНГОЛОИДНОЙ РАСЫ. ЧАСТЬ 1. ХАРАКТЕРИСТИКА КРАНИОСЕРИЙ СЕВЕРНЫХ МОНГОЛОИДОВ*
}

\begin{abstract}
Исследовалось 52 современные краниологические серии северных монголоидов территории Западной и Восточной Сибири, Дальнего Востока, Центральной Азии и Казахстана, по литературным источникам. По краниологической концепции Н. Н. Чебоксарова их относят к континентальному варианту монголоидов. Анализировались различия среднегрупповых величин 11 метрических признаков этих серий-параметров размера и формы черепной коробки. Изученные краниосерии в целом представляют собой один из трёх выделенных нами ранее панойкуменных краниотипов - голарктидов, характеризующихся по мировым масштабам средней величиной черепной коробки, а по форме среднеудлинённой, широкой и низкосводной. Дендрограмма взаимных расстояний среди изученных краниосерий выявила три кластера, почти равных по численности серий, и достоверно различающихся между собой по трём из одиннадиати сравниваемых признаков. Первый кластер (18 краниосерий) по краниологическим характеристикам наиболее отличен от типичного облика голарктидов и, по нашему мнению, представляет собой хронологически наиболее ранний этап эволючионного развития краниотипа голарктидов. Два других кластера характеризуют более крупноголовый и мелкоголовый варианты типичных восточных голарктидов.
\end{abstract}

Ключевые слова: мозговой череп, краниосерия, краниотип, степень сферичности черепа, эволючионные изменения

Ссылка при цитировании: Пестряков А.П., Григорьева О.М., Пеленицына Ю.В. Краниологическая дифференциация большой монголоидной расы. Часть 1. Характеристика краниосерий северных монголоидов // Вестник антропологии, 2021. № 2. С. 274-291.

Пестряков Александр Петрович - к.и.н., старший научный сотрудник Центра физической антропологии, Институт этнологии и антропологии РАН (Москва, Ленинский пр. 32-а) Эл. почта: labrecon@yandex.ru

Григорьева Ольга Михайловна - к.б.н., старший научный сотрудник Центра физической антропологии, Институт этнологии и антропологии РАН (Москва, Ленинский пр. 32-а) Эл. почта: labrecon@yandex.ru

Пеленицына Юлия Вадимовна - студентка кафедры антропологии биологического факультета МГУ им. М.В. Ломоносова (119234 Москва, Ленинские горы, 1/12) Эл. почта: j.pelenitsyna@gmail.com

* Исследование выполнено в рамках темы НИР «Эволюционный континуум рода Ното». Подтема «Антропология древних и современных популяций» 


\section{Введение}

Монголоидная раса является одной из трёх (по другой схеме четырёх) больших рас современного человечества. Зоной её традиционного расселения является практически вся восточная половина континента Азии, а также бо̀льшая часть островного мира между Азией и Австралией. Благодаря усилиям отечественных антропологов середины прошлого века разработана расово-морфологическая дифференциация монголоидов Азии (Чебоксаров 1947, 1951; Дебец 1951). В массиве азиатских монголоидов ими было выделено четыре расовых варианта: северные монголоиды (территория Северной и Центральной Азии, восточные монголоиды (территория Китая, Кореи и Японии), южные монголоиды (территория Индонезии и Индокитая), арктические монголоиды (крайний северо-восток азиатского континента). По краниологическим признакам Н.Н. Чебоксаров также разделял монголоидов на два различных типа: тихоокеанские и континентальные монголоиды. При этом для восточных монголоидов характерен тихоокеанский краниотип, а для северных - континентальный.

В начале XX века профессор В.В. Бунак указывал на необходимость создания особой краниологической классификации человечества, отличной от расовой. При этом при её создании он считал наиболее важным учитывать величины трёх основных диаметров черепной коробки и их взаимные отношения (Бунак 1923). Опираясь на эту основополагающую идею В.В. Бунака, одному из авторов настоящей статьи в конце XX века удалось создать рабочую схему краниологической классификации современного человечества (Пестряков 1995). Более полная версия этой классификации опубликована несколько позднее (Пестряков, Григорьева 2004). В этих работах описаны особенности и территории распространения трёх основных (панойкуменных) краниотипов современности: голарктидов, тропидов и пацифидов. Кроме этого также выделены два локальных краниотипа, отличных от вышеназванных: тропические пацифиды и капоиды. В процессе дальнейшей работы введение определенных коррективов принципиально не изменили нашей краниологической системы. Следует помнить, что эта классификация касается особенностей (размеры и форма) только черепной коробки, этого вместилища огромного человеческого головного мозга. Лицевой (висцеральный) скелет человека имеет иную функциональную нагрузку и поэтому имеет относительно слабую онтогенетическую и филогенетическую связь с морфологическими особенностями скелета мозгового черепа. Поэтому параметры висцерального скелета в данной классификации не учитываются.

Настоящая статья посвящена изучению краниологического разнообразия большой монголоидной расы, а именно северным монголоидам, континентальным согласно дихотомическому делению Н.Н. Чебоксарова, голарктидам, согласно нашей классификации.

Хорошо известно, что краниологическая дифференциация человечества лишь частично совпадает с расовой. Большая часть северных монголоидов принадлежит к малой североазиатской расе, состоящей из двух антропологических вариантов - байкальского, доминирующего на территории Восточной Сибири и Дальнего Востока, и центральноазиатского, доминирующего на территории Центральной Азии. Здесь следует особо подчеркнуть, что под Центральной Азией мы понимаем территорию с соответствующими ей физико-географическими характерными особенностями, а не современное территориально-политическое подразделение, куда включают новообразованные среднеазиатские государства. 
К популяциям североазиатской малой монголоидной расы территориально и морфологически примыкают две метисные монголоидно-европеоидные малые расы: уральская и южносибирская), а также арктическая малая раса крайнего северо-востока Азии.

\section{Материалы и методы}

Исследованы 52 краниосерии. Краниологические характеристики изучаемых краниосерий этого обширного региона взяты из соответствующих литературных источников. Краниосерии населения Западной Сибири: манси, хантов, ненцев, селькупов, чулымцев, шорцев, этнические группы алтайцев и территориальные группы сибирских татар изучались Г.Ф. Дебецем (Дебеи 1951), Н.С. Розовым (Розов 1956), А.Н. Багашёвым (Багашёв 1991, 1999, 2000), В.А. Дрёмовым (Дрёмов 1991а, 1991б), А.Р. Кимом (Ким 1978а, 1978б, 1984) и другими антропологами. Почти все среднегрупповые величины необходимых нам краниологических признаков краниосерий этих этносов представлены в обобщающих таблицах фундаментальной монографии А.Н. Багашёва (Багашёв 2000).

Краниология современного населения Восточной Сибири также изучалась многими антропологами. Хакасы Минусинской котловины были изучены В.П. Алексеевым (Алексеев 1960а). Он же исследовал в это же время краниологию тувинцев (Алексеев 1960б) и тофаларов (Алексеев 1960в). Данные по краниологии казахов взяты из книги О. Исмагулова (Исмагулов 1970), а по краниологии киргизов из работы Н.Н. Миклашевской (Миклашевская 1959).

Материалы по краниологии населения Восточной Сибири и Дальнего Востока взяты нами в основном из обширной сводной работы В.П. Алексеева и И.И. Гохмана (Алексеев, Гохман 1984).

Ниже в таблицах представлены краниологические характеристики изучаемых серий. Среднегрупповые величины трёх диаметров черепной коробки каждой краниологической серии - наибольший продольный диаметр (признак 1, по списку Мартина), наибольший поперечный диаметр (признак 8, по Мартину) и высотный диаметр от базиона (признак 17, по Мартину) взяты из соответствующей литературы. Остальные 8 метрических параметров вычислялись, исходя из среднегрупповых величин этих диаметров. Общая ростовая величина черепной коробки (ОРВ) вычисляется векторным сложением величин трёх взаимно-перпендикулярных её диаметров по формуле: ОРВ $=\left(1^{2}+8^{2}+17^{2}\right)^{1 / 2}$. Далее в таблице следуют величины следующих индексов: черепной $(8: 1)$, высотно-продольный $(17: 1)$ и высотно-поперечный (17:8) указатели. Затем идут указатели, связывающие величины всех трёх диаметров черепа: указатель долихоидности (УД), брахиоидности (УБ), гипсиоидности (УГ). Они представляют собой средние геометрические отношения каждого из трех названных диаметров черепной коробки к двум оставшимся (в \%). Например, УД = $100 *\left[\left(1^{2} /(8 * 17)\right]^{1 / 2}\right.$. И так далее. Последний параметр - степень сферичности (СС) объединяет значения трёх этих указателей, рассчитывается по формуле $\mathrm{CC}=(200$ УД +УБ+УГ)/3. Чем ближе эта величина к 100, тем более черепная коробки приближается по форме к сфере.

В нижерасположенной таблице даны среднегрупповые величины этих признаков по всем изучаемым в настоящей работе 52-м краниосериям. 
㿣

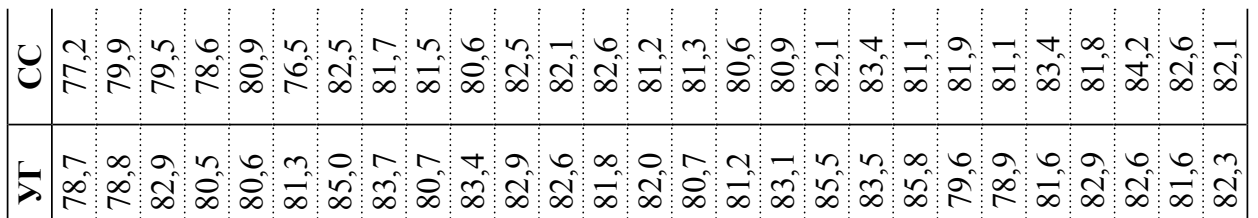

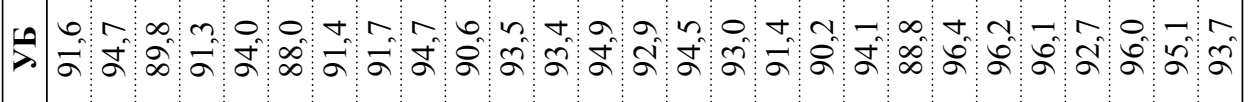

7.

$\because \nabla^{\prime} \infty$ o

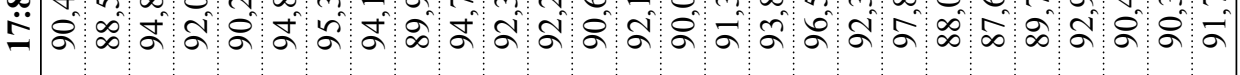

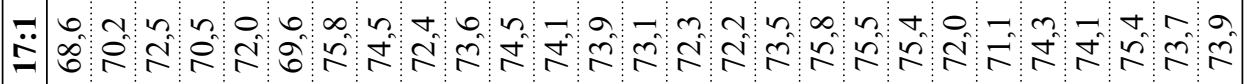

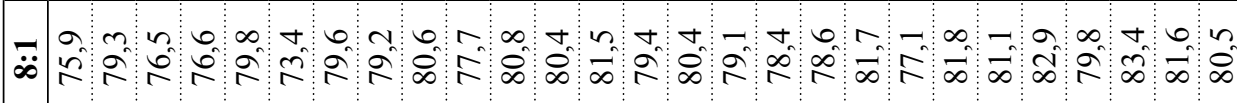

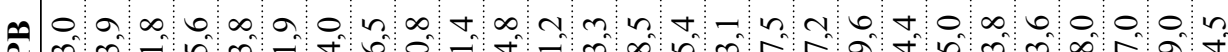

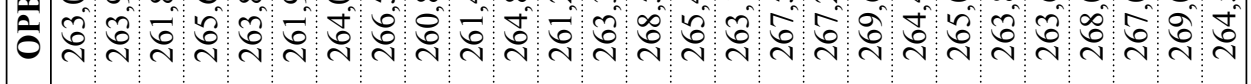

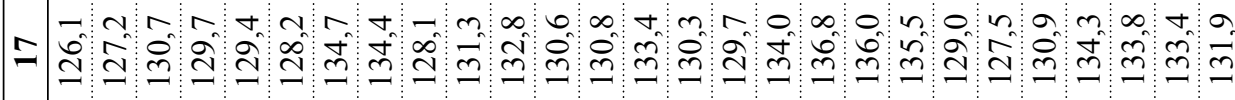

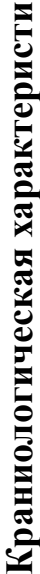

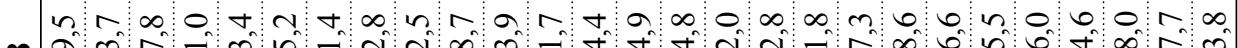

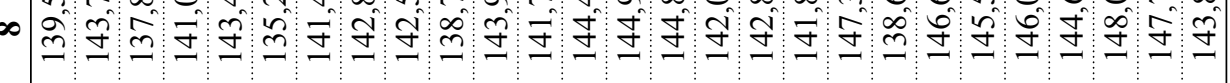

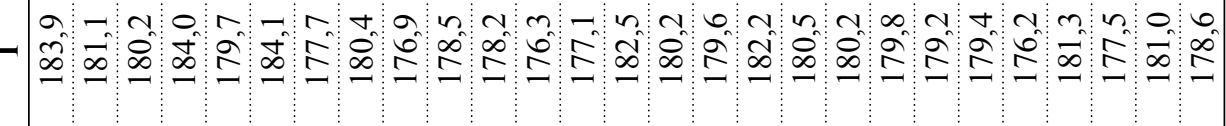

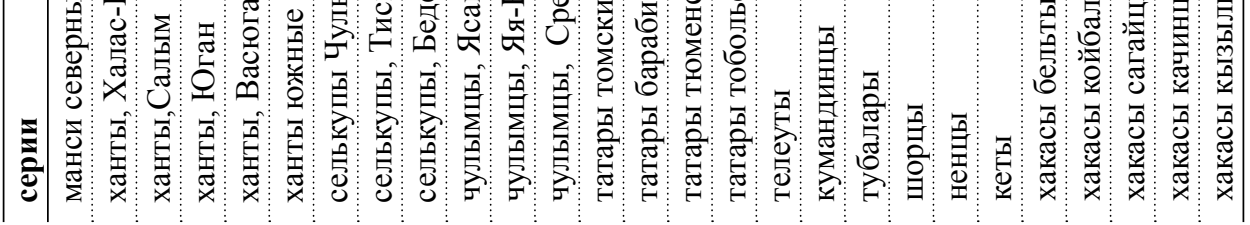




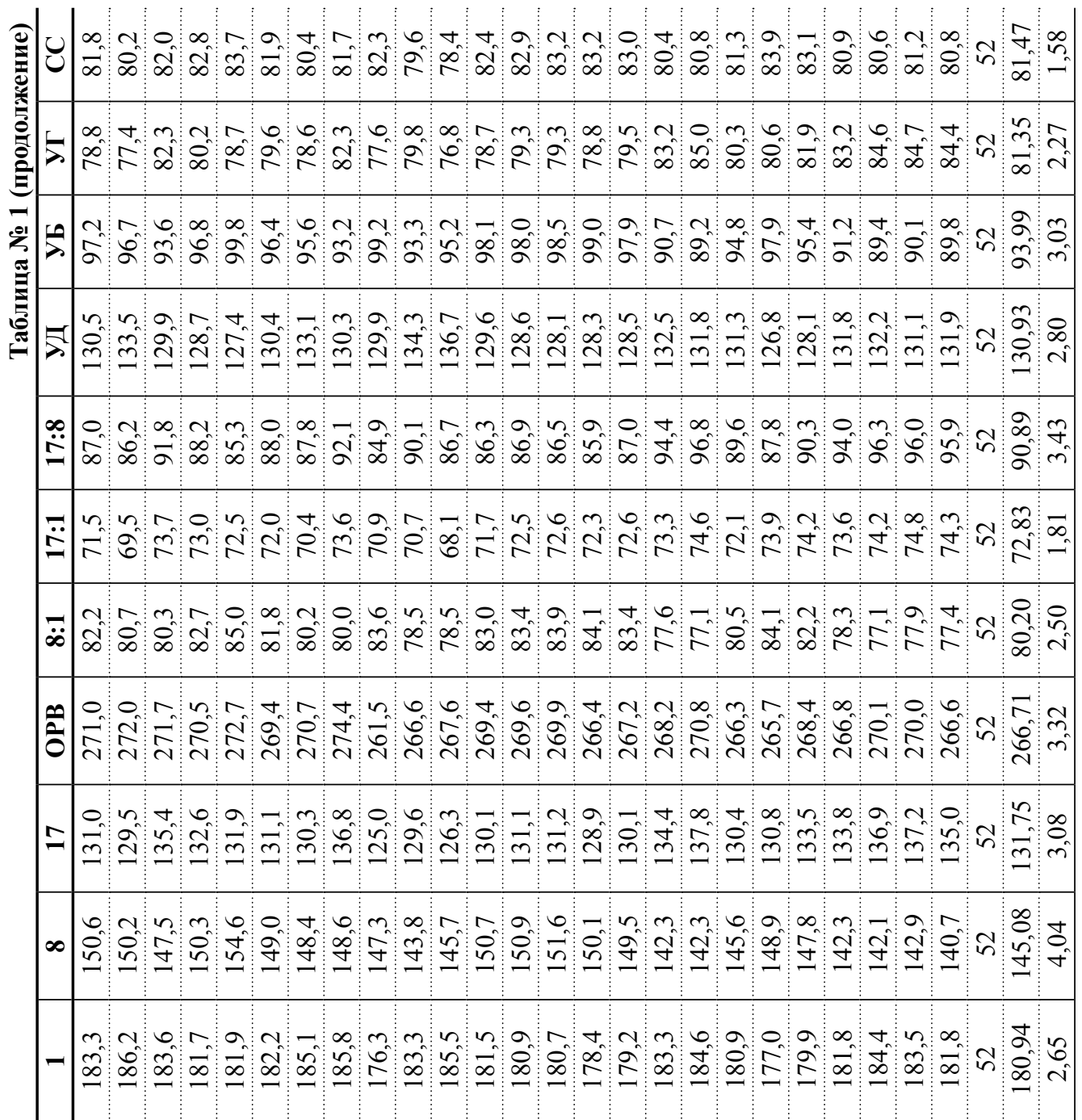

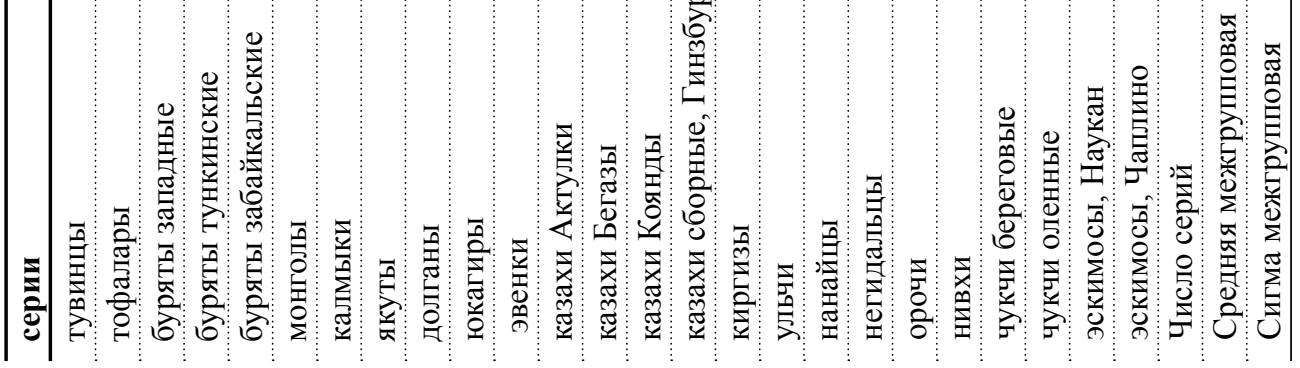




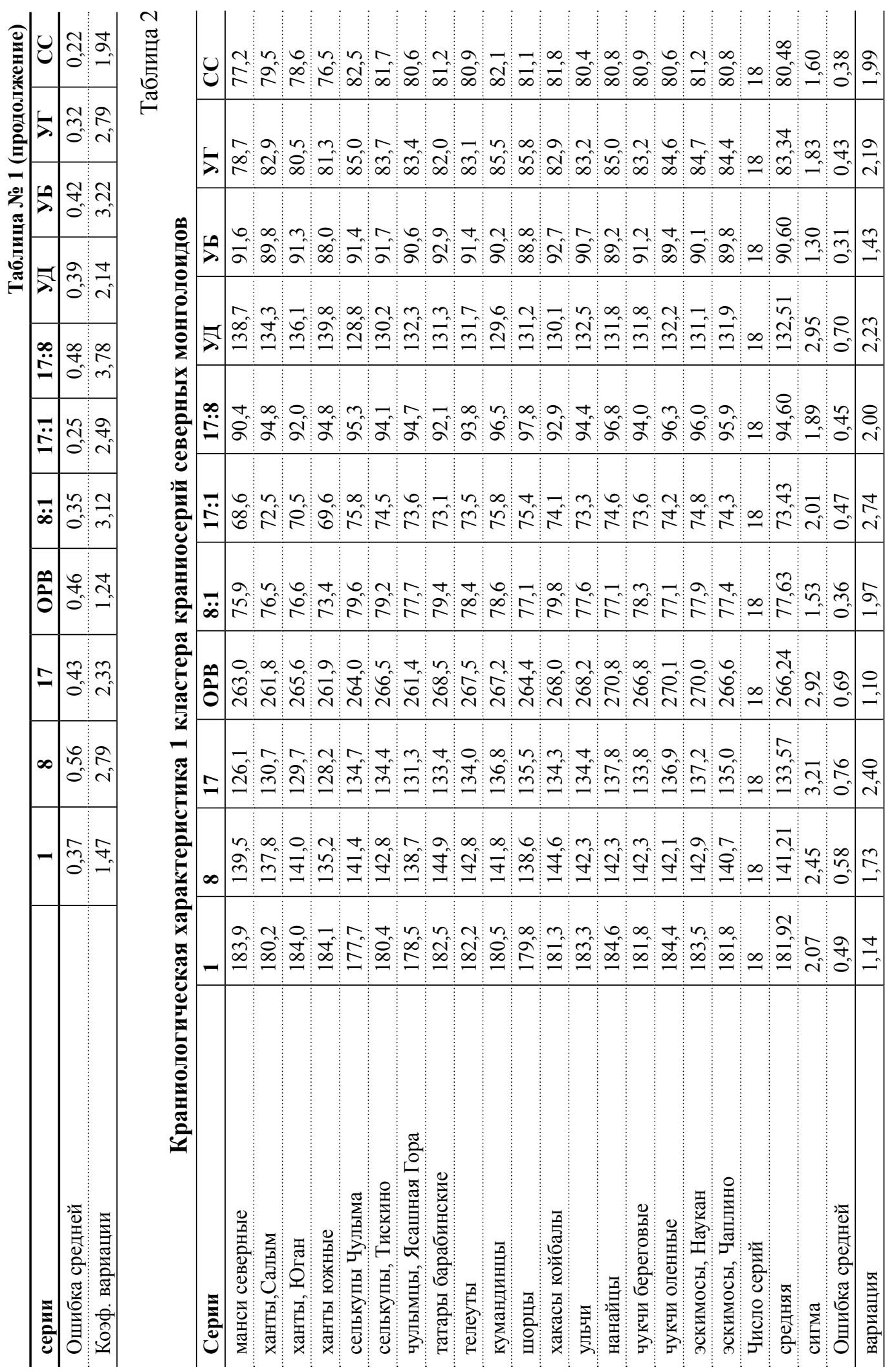


㫯

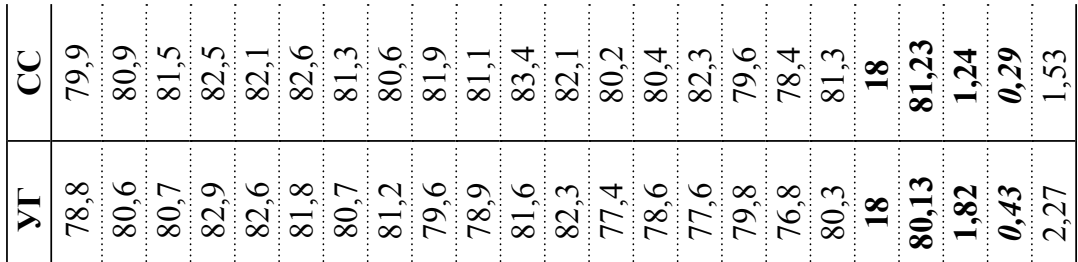
है

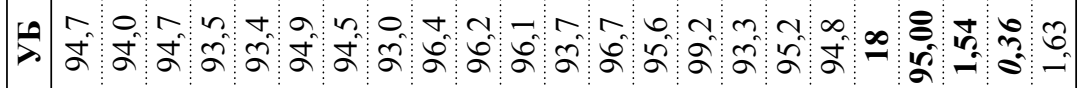

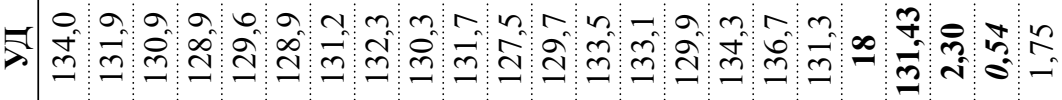

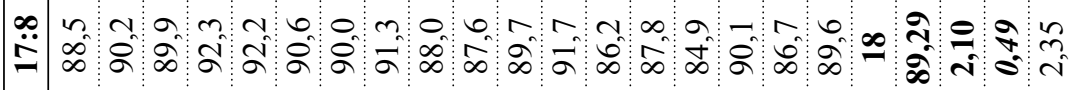

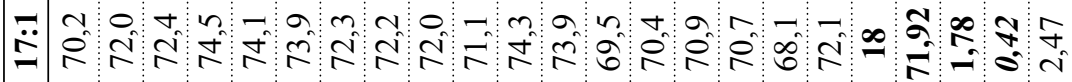

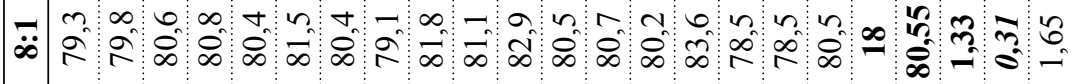

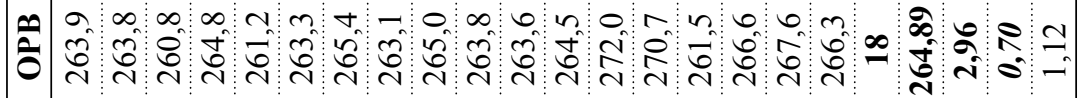

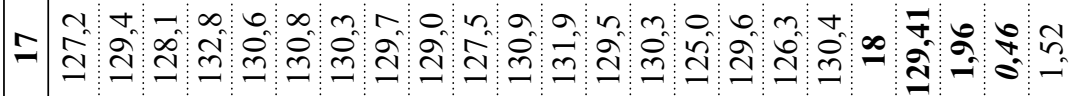

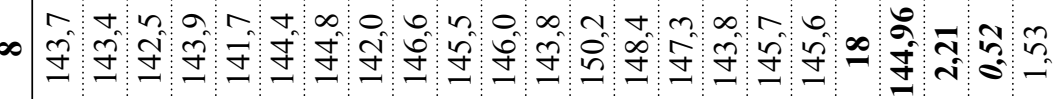

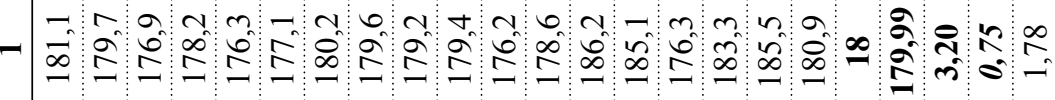

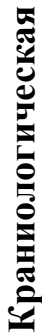

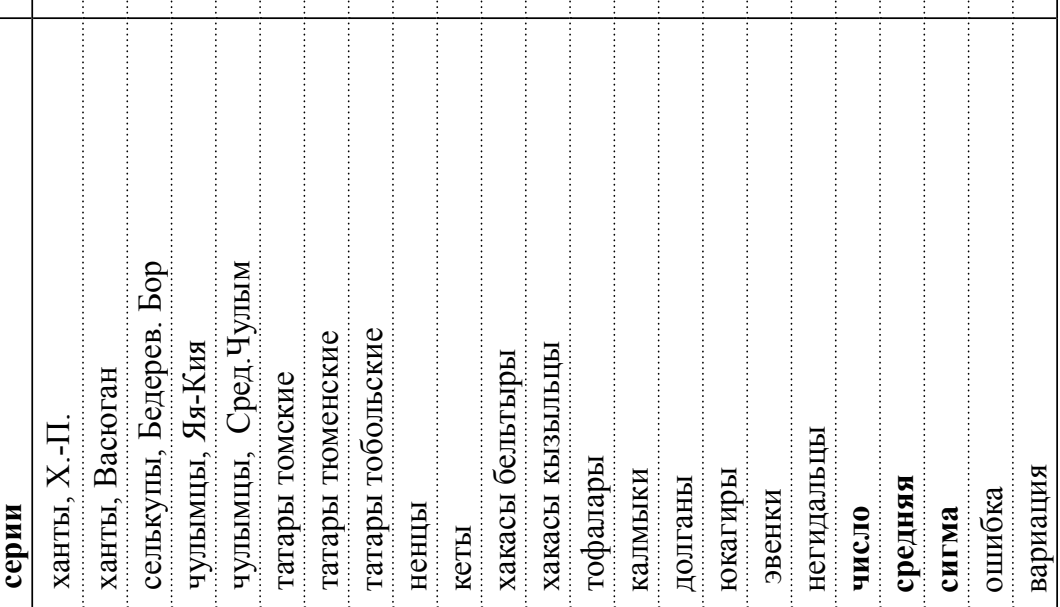


Средняя межгрупповая величина черепной коробки (признак ОРВ) здесь по мировому масштабу средняя, но приближается к большой. Из трёх основных диаметров черепа в межгрупповом отношении наименее вариабельным оказался его продольный диаметр. Стандартное отклонение его средней величины $\sigma=2,65$, а коэффициент вариации - 1,47. Наиболее вариабелен широтный диаметр (б =4,04, а коэффициент вариации $=2,79)$. Изменчивость высотного диаметра здесь занимает промежуточное положение. По форме черепа здесь преобладает брахикрания (29 серий), хотя одна серия из 52-х долихокранная, а 22 - мезокранных. По обобщённым указателям формы в целом, здесь наблюдается следующая картина: указатель долихоидности имеет среднюю величину (УД=130,93), указатель брахиоидности большую (УБ=93,99), а указатель гипсиоидности - малую (УГ=81,35). По этим краниологическим признакам этот массив серий, как целое, следует отнести к панойкуменному краниотипу голарктидов.

По данным таблицы 1 построена дендрограмма взаимных расстояний между сериями с учётом величин всех 11 признаков (рис. 1).

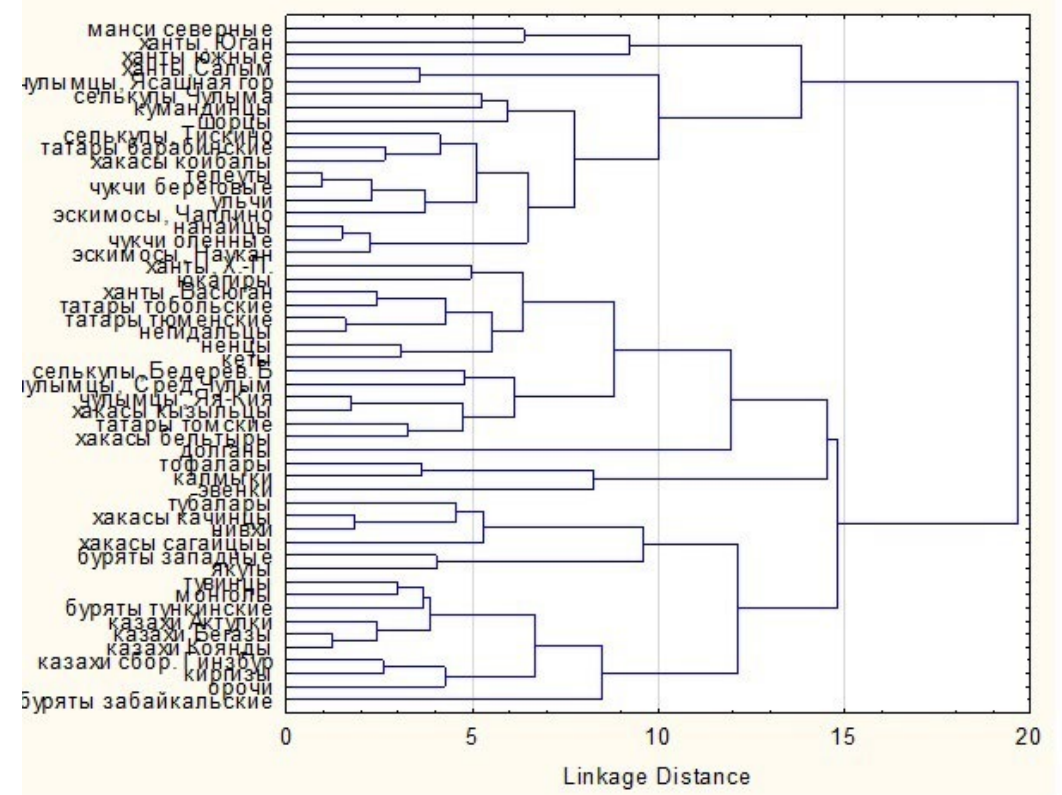

Рис.1. Дендрограмма расстояний между краниосериями северных монголоидов по 11 признакам размера и формы черепной коробки.

Здесь чётко выделяются три кластера-фракции (счёт идёт сверху): 1-й кластер (18 серий), 2-ой (18 серий) и 3-ий (16 серий). Краниологические характеристики их представлены в таблицах 2, 3 и 4, соответственно.

В этот кластер попадает основной массив краниосерий территории Западной Сибири: серия манси, 3 из 5 серий хантов, 2 из 3 серий селькупов, одна из трёх серий чулымцев, серия шорцев, 2 из трёх серий алтайцев, одна из 4 серий западносибирских татар. Кроме этого, сюда входит одна из 5 серий хакасов (доминирующих в Минусинской котловине Восточной Сибири) и, что совсем неожиданно, краниосерии территории Дальнего Востока: серии ульчей и нанайцев Хабаровского края, чукчи (2 серии) и эскимосы (2 серии) с территории крайнего северо-востока нашей страны. 
Из 18 серий этого кластера нет ни одной брахикранной, что противоречит отнесению серий этого кластера к краниотипу типичных пацифидов.

Ниже представлены данные краниосерий, входящих во второй кластер нашей дендрограммы.

Здесь представлены серии населения Западной Сибири, не вошедшие в 1-й кластер дендрограммы. Кроме них здесь представлены: серии кетов, ненцев, долган, юкагиров, эвенков, две серии хакасов, тофалары с территории Восточной Сибири, а также калмыков и одна дальневосточная серия негидальцев. Как видно, эти краниосери занимают не только часть территории Западной Сибири, но также и часть Восточной Сибири. При этом сюда попадают наиболее северные из изученных серий: ненцы, долганы, юкагиры. Здесь 5 краниосерий мезокранные, остальные 13 брахикранные.

В таблице 4 даны краниологические характеристики серий 3-его кластера дендрогаммы.

В таблице 4 представлены: серия тубаларов, две серии хакасов, все серии центральноазиатской расы (буряты, монголы, тувинцы), серия якутов (недавних выходцев из Центральной Азии), все четыре серии казахов, а также две дальневосточные серии орочей и нивхов. Обращает внимание, что за исключением серии тубаларов (северный Алтай) и двух дальневосточных серий, все остальные названные здесь принадлежат кочевникам, коневодам Великой евразийской степи. Здесь все 16 серий брахикранные.

В следующей таблице 5 сравниваются величины всех 11 параметры трёх кластеров со всем массивом изучаемых краниосерий, а также кластеров между собой.

Достоверность различия изучаемых величин рассчитывалась по t-критерию Стьюдента согласно методике учебника по биометрии Н.А. Плохинского (Плохинский 1961). Достоверность различия отмечалась символом *.

Согласно данным этой таблицы наименьшее отличие от всего массива краниосерий показал второй, выделенный нами кластер: недостоверны отличия по 7, достоверны по 4 из 11 наличных признаков. У первого и третьего кластеров наоборот недостоверны различия 4 признакам, достоверны по 7. Таким образом, серии второго кластера (как целое) определённо значительно более сходны с общей характеристикой всего массива изучаемых серий, чем серии двух других кластеров (первого и третьего).

Серии первого кластера самые удлинённые абсолютно (продольный диаметр равен 181,9 мм) и по форме (черепной указатель $=77,6$, а УД=132,5). Они же абсолютно (высота от базиона $=133,6)$ и относительно $(У Г=83,3)$ самые высокосводые. Степень сферичности черепной коробки здесь минимальна $(\mathrm{CC}=80,48)$.

Серии второго кластера наименьшие по размеру черепной коробки $(\mathrm{OPB}=264,9)$, самые низкие абсолютно (129,4 мм) и относительно (УГ=80,13).

Серии третьего кластера наиболее крупноголовые $(\mathrm{OPB}=269,5)$. По мировому масштабу по нашей рубрикации - это большая величина (у двух других кластеров средняя). Для этой фракции характерна наибольшая абсолютная (149,6 мм) и относительная (УБ=96,7) черепной коробки. Здесь все серии брахикранные и степень сферичности максимальна $(\mathrm{CC}=82,85)$. 
๑

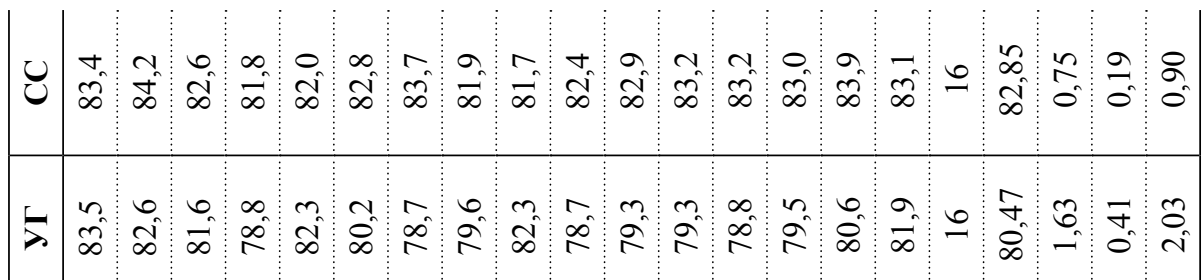

光

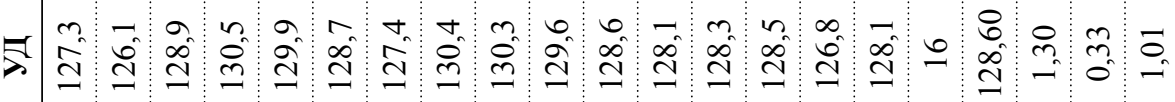

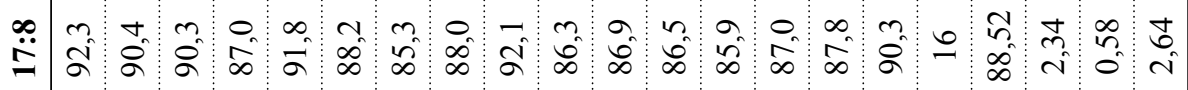

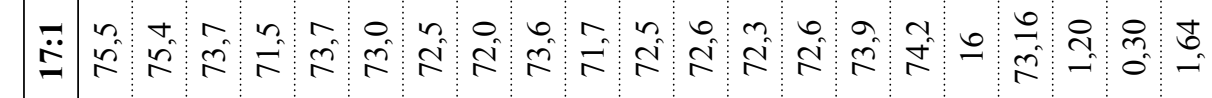

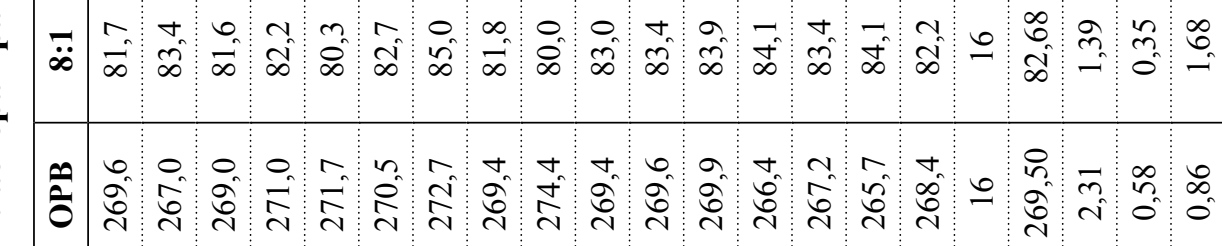

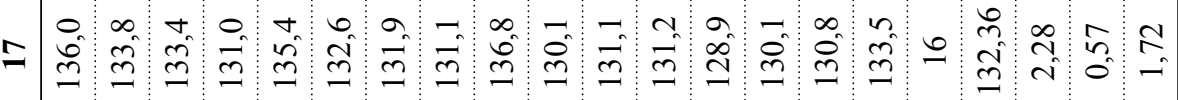

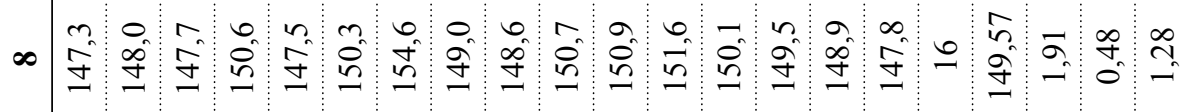

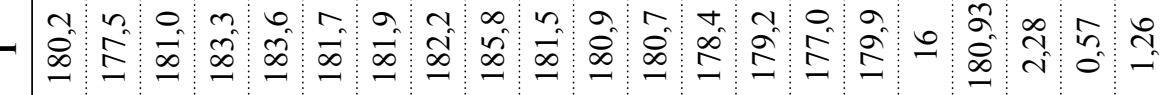

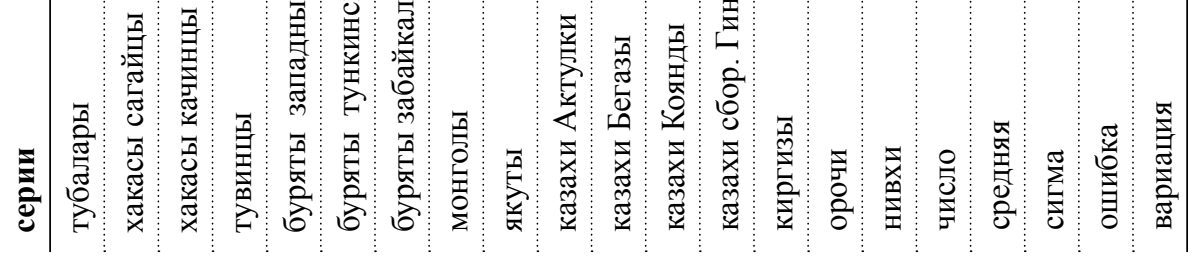




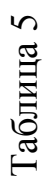

\begin{tabular}{|c|c|c|c|c|c|c|c|c|c|c|c|c|c|c|c|}
\hline U U & 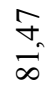 & $\stackrel{\infty}{\stackrel{\infty}{\infty}} \underset{\infty}{\infty}$ & $\underset{\infty}{\stackrel{\infty}{n}}$ & $\begin{array}{l}2 \\
\infty \\
\infty \\
\infty\end{array}$ & ळे & $*$ & त̂ & $\underset{]}{E}$ & $\stackrel{\infty}{\sim}$ & 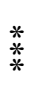 & $\frac{0}{0}$ & $\stackrel{\vec{\Phi}}{\tilde{\Phi}}$ & $\hat{\tilde{m}}$ & 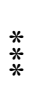 & $\stackrel{\overrightarrow{6}}{-}$ \\
\hline$E$ & $\underset{\infty}{n}$ & $\begin{array}{l}\dot{m} \\
\infty_{\infty}\end{array}$ & $\frac{m}{\infty}$ & $\begin{array}{l}\text { f } \\
\stackrel{\infty}{\infty}\end{array}$ & $\stackrel{\partial}{-}$ & $*$ & $\tilde{\sim}$ & * & $\begin{array}{l}\infty \\
\infty \\
0 \\
0\end{array}$ & $\underset{\mathbb{I}}{\tilde{y}}$ & $\overrightarrow{\tilde{N}}$ & $*$ & $\begin{array}{l}\hat{\infty} \\
i \\
i\end{array}$ & 苂 & $\hat{m}^{m}$ \\
\hline
\end{tabular}

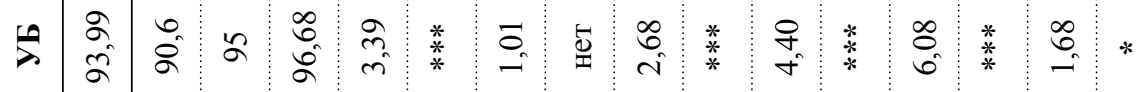

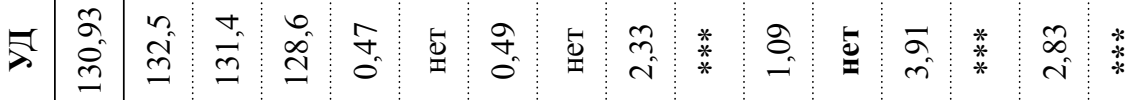

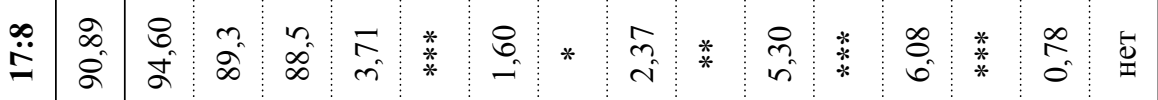

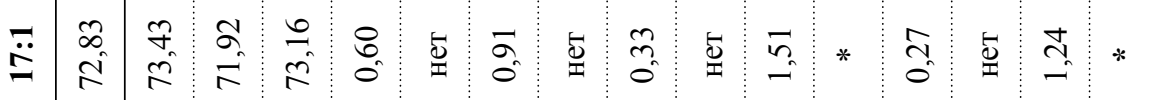

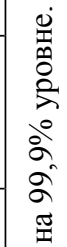

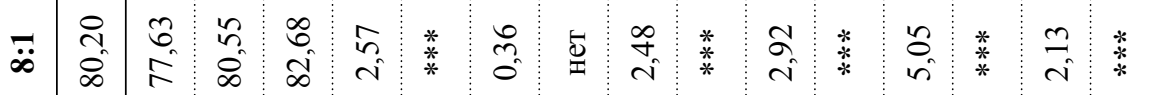

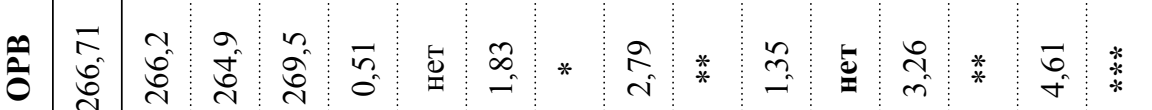

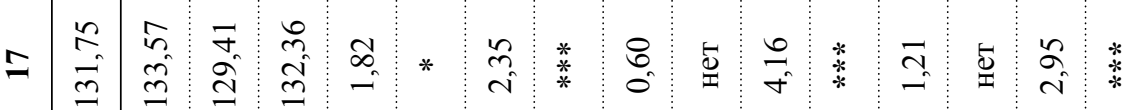

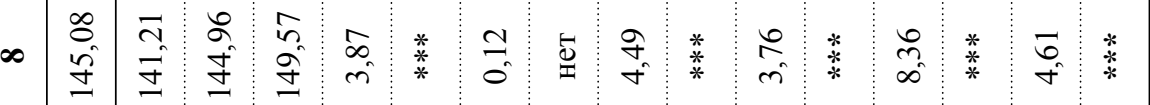

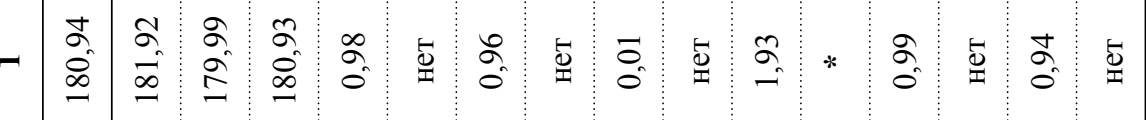

ב

\begin{tabular}{|c|c|c|c|c|c|c|c|c|c|c|c|c|}
\hline 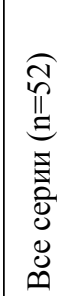 & 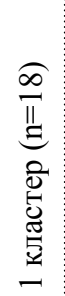 & 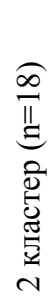 & 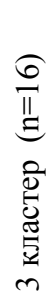 & 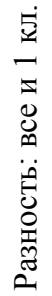 & $\begin{array}{l}\text { : } \\
0 \\
0 \\
0 \\
0 \\
0 \\
0 \\
0 \\
0 \\
0 \\
0\end{array}$ & 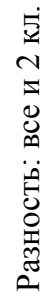 & 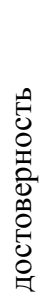 & 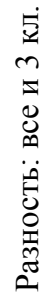 & $\begin{array}{l}\hat{0} \\
0 \\
0 \\
0 \\
0 \\
0 \\
0 \\
0 \\
0 \\
0 \\
0 \\
0\end{array}$ & $\begin{array}{l}5 \\
0 \\
0 \\
0 \\
0 \\
0 \\
0\end{array}$ & & \\
\hline
\end{tabular}




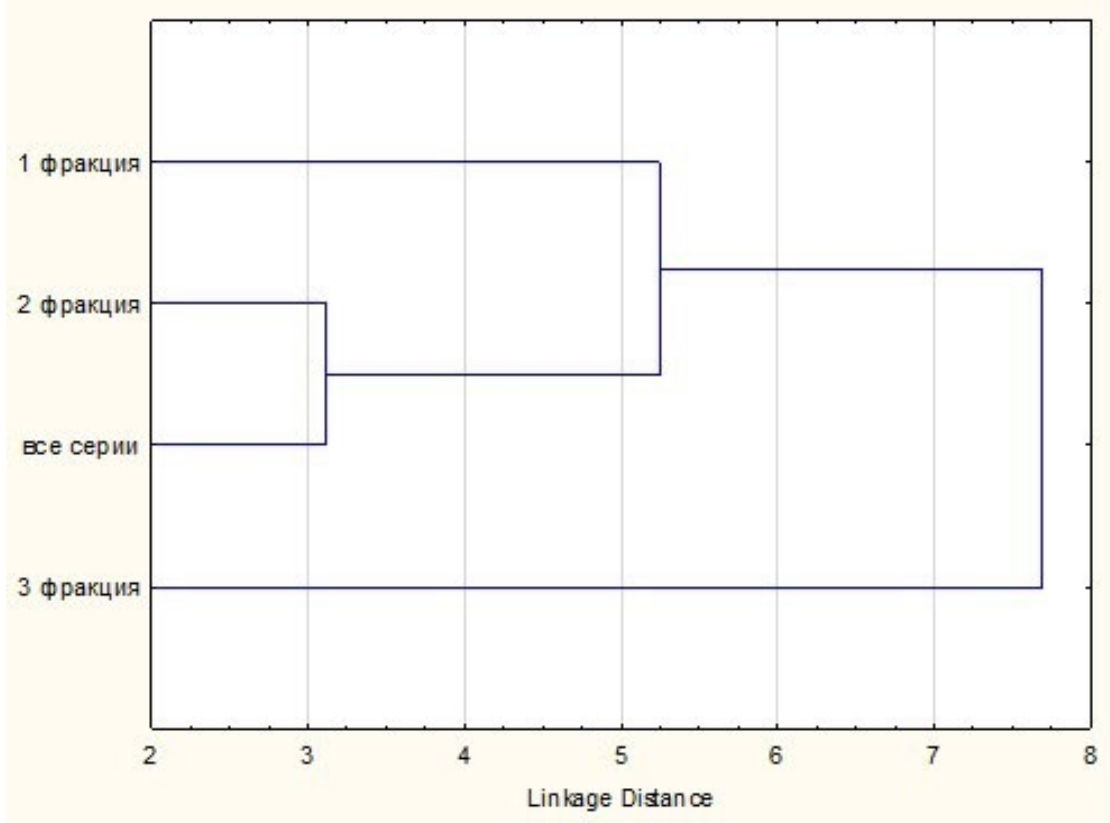

Рис. 2. Кластеризация по признакам величины черепной коробки.

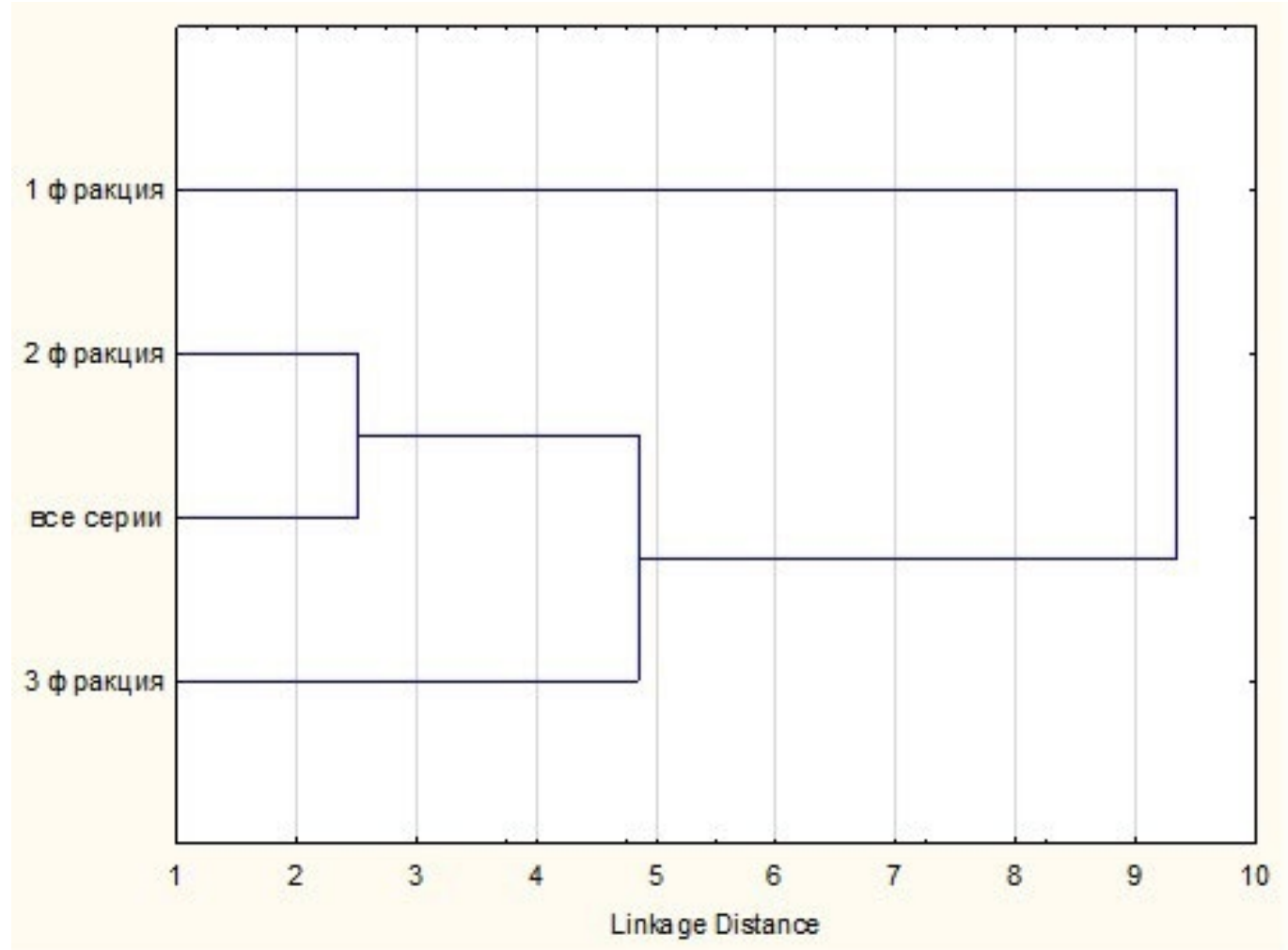

Рис. 3. Кластеризачия по признакам формы черепной коробки. 
В двух ниже приведённых дендрограммах (рис.2 и рис.3) показаны таксономические расстояния трёх наших кластеров между собой и с массивом всех изучаемых краниосерий.

Как и следовало ожидать, вторая фракция почти в два с половиной раза ближе к общему массиву, чем первая и почти в четыре раза чем третья. Третья фракция выделяется в основном благодаря большой абсолютной величине черепа и наибольшей величине поперечного диаметра, входящих в неё серий. Первая фракция выделяется наибольшей длиной и высотой черепа.

Здесь в наибольшем отдалении оказались серии первой фракции. Они более чем в 3,5 раза дальше отстоят от общего массива серий, чем серии второй фракции. Серии третьей фракции лишь в два с небольшим отстоят дальше от общего массива, чем серии второй фракции.

Исходя из приведённого сравнительного анализа, можно считать, что вся совокупность изучаемого материала (52 серии) как целого и по абсолютным размерам, и по форме черепа наиболее близка к краниосериям второго кластера. К тому же эти серии занимают обширную область в центре изучаемого региона. Краниосерии 1-го и 3-его кластеров как бы окаймляют этот центр с запада (западносибирские группы), востока (серии Хабаровского края и Чукотки) и юга (серии кочевых этносов Южной Сибири и Казахстана).

Итак, можно обоснованно предположить, что именно краниосерии второго нашего кластера были исходным краниотипом изучаемого региона. Облик других краниосерий, вероятно, сформировался в результате метисации внешних периферических популяций с представителями этого исходного краниотипа.

Однако, можно аргументировано отстаивать и другой вариант краниологической эволюции популяций изучаемого обширного региона.

Если исходить из номогенетического принципа эволюционного изменения биологических признаков вида (Берг 1977), то необходимо представить какой-либо важный ведущий признак, имеющий выраженную хронологически направленную изменчивость. Таковым здесь может быть степень сферичности черепной коробки (CC). В нашей более ранней работе (Пестряков 1991) была показана диахронная изменчивость этого признака в двух обширных регионах Старого Света (Европа и Восточная Азия) от верхнего палеолита до современности. На территории Европы за этот период величина признака СС увеличилась от 76,6 до 81,9, а в Восточной Азии от 75,7 до 82,2. Причём особенно интенсивно этот процесс шёл в последнее тысячелетие.

В настоящей работе мы не анализируем диахронную изменчивость этого признака на изучаемой территории Северной Азии. Для этого необходимо провести объёмное исследование, выходящее за рамки задачи, обозначенной в наименовании статьи. Однако мы можем воспользоваться данными по изменению краниологических характеристик населения Восточной Европы, региона соседнего с территорией Северной Азии (Веселовская, Григорьева, Пестряков, Рассказова 2005). В этой статье сравнивались краниологические характеристики 25-ти серий раннесредневековых восточных славян с 23-мя сериями русских Нового времени, наиболее вероятных потомков этих славян. Хронологический разрыв между ними чуть более половины тысячелетия. В таблице 6 даны средние межгрупповые величины 11 признаков этих объединений и статистическая достоверность различия между ними. В этой же таблицы представлены краниологические характеристики двух наших синхронных объединений сибирских краниосерий (кластер 1 и кластер 2) и достоверность различия между ними. 
Таблица 6

Сравнение краниологических характеристик серий славян с сериями русских и серий 1 и 2 кластеров изучаемого региона

\begin{tabular}{|c|c|c|c|c|c|c|c|c|c|c|c|}
\hline & 1 & 8 & 17 & OPB & $8: 1$ & $17: 1$ & $17: 8$ & УД & УБ & $\mathbf{У Г}$ & $\mathrm{CC}$ \\
\hline $\begin{array}{l}\text { Вост. } \\
\text { славяне } \\
(n=25)\end{array}$ & 185,0 & 137,5 & 135,7 & 267,6 & 74,3 & 73,5 & 98,4 & 135,5 & 86,9 & 85,2 & 78,8 \\
\hline $\begin{array}{l}\text { Русские } \\
(\mathrm{n}=23)\end{array}$ & 178,3 & 143,6 & 134,6 & 265,5 & 80,6 & 75,5 & 93,7 & 128,4 & 92,7 & 84,1 & 82,8 \\
\hline $\begin{array}{l}\text { Достовер. } \\
\text { различия }\end{array}$ & $* * *$ & $* * *$ & * & * & $* * *$ & $* * *$ & $* * *$ & $* * *$ & $* * *$ & $* *$ & $* * *$ \\
\hline $\begin{array}{l}1 \text { кластер } \\
(\mathrm{n}=18)\end{array}$ & 181,9 & 141,2 & 133,6 & 266,2 & 77,6 & 73,4 & 94,6 & 132,5 & 90,6 & 83,3 & 80,5 \\
\hline $\begin{array}{l}2 \text { кластер } \\
(\mathrm{n}=18)\end{array}$ & 180,0 & 145,0 & 129,4 & 264,9 & 80,6 & 71,9 & 89,3 & 131,4 & 95,0 & 80,1 & 81,2 \\
\hline $\begin{array}{l}\text { Достовер. } \\
\text { различия }\end{array}$ & $*$ & $* * *$ & $* * *$ & Нет & $* * *$ & $*$ & $* * *$ & нет & $* * *$ & $* * *$ & нет \\
\hline
\end{tabular}

Примечание. * - различие достоверно на 95\% уровне значимости, ** - на 99\% уровне, *** на $99,9 \%$ уровне.

Из этой таблицы хорошо видно сходство отличий краниосерий восточных славян с русскими сериями, с одной стороны, и отличий 1 кластера с 2 кластером, изучаемого здесь региона Северной Азии, с другой стороны.

Между восточными славянами и русскими сериями различие достоверно по всем используемым краниологическим признакам, правда, с разной степень достоверности (см. третью строку таблицы 6). Продольный и высотный диаметры черепа у славян больше, чем у русских, но поперечный диаметр меньше. Общая величина черепной коробки у славян несколько больше. Русские - умеренные брахикраны, славяне - выраженные долихокраны. Славяне по форме черепа более долихоидные и гипсиоидные, чем русские, последние более брахиоидные. Наконец, степень сферичности у русских значительно более выражена, чем у славян $(82,8$ против 78,8$)$.

При сравнении характеристик 1-го и 2-го кластеров сибирских серий почти полностью повторяются те же отличия, что обнаружены при сравнении славян и русских. При этом на месте славян оказывается выделенный нами первый кластер, на месте русских - второй. Однако, следует сказать, что отличия величин трёх параметров (ОРВ, УД, СС) между этими кластерами достоверны не всегда. Хотя их изменения идут в том же направлении, что и при сравнении восточных славян с русскими.

Исходя из этого, следует предположить, что в Северной Азии идёт процесс изменения краниологического облика населения в сторону усиления типичных свойств голарктидов (брахикефализация, абсолютное и относительное уменьшение длины и высоты черепной коробки, при таком же увеличении её ширины, увеличение сферичности черепа), подобно такому же процессу, который в Восточной Европе среди славянского населения в этом направлении зашёл заметно дальше. 


\section{Выводы}

1. Краниологические серии северных монголоидов в целом представляют собой панойкуменный краниотип голарктидов, характеризующихся по мировым масштабам средней величиной черепной коробки, по форме среднеудлинённой, широкой и низкосводной.

2. Исследованные по 11 метрическим признакам, 52 краниосерии изучаемого региона довольно чётко разбиваются на три различных кластера, имеющих довольно выраженную территориальную приуроченность. Первый кластер окаймляет регион с запада (большинство серий Западной Сибири) и с востока (большинство серий Хабаровского края и Чукотки). Третий кластер состоит в подавляющем большинстве кочевых степных групп Южной Сибири и Казахстана. Серии второго кластера занимают срединное положение (центр и север Восточной Сибири).

3. Серии этих кластеров по большинству изучаемых признаков достоверно отличаются друг от друга. Серии третьего кластера наиболее крупноголовые, абсолютно и относительно наиболее широкоголовые, по форме менее удлинённые и наиболее сферичные. У них наиболее выражен краниологический облик голарктидов. Менее всего он выражен у краниосерий первого кластера, мезокранных, абсолютно и относительно наиболее удлинённых и высокосводных, наименее сферичных. Краниосерии второго кластера, самые малоголовые, по большинству параметров формы занимают промежуточное положение между первым и третьим кластерами. Их характеристические особенности, вероятно, проявились в результате хронологических изменений краниосерий типа первого кластера.

4. Анализ диахронной изменчивости краниотипов Северной Азии, и ее причины требует дальнейшего исследования, опирающегося на краниологические данные серий, более ранних периодов истории этого региона.

\section{Научная литература}

Алексеев В.П. Краниология хакасов в связи с вопросами их происхождения // Труды Киргизской археолого-этнографической экспедиции. 1960a. T. IV. С. 269-364.

Алексеев В.П. Материалы к палеоантропологии западной Тувы // Труды Тувинской комплексной археолого-этнографической экспедиции. 1960б. Т. І. С. 284-316.

Алексеев В.П. К краниологии тофаларов // Вопросы антропологии. М.: Издательство Московского Университета, 1960. Вып. 5. С. 122-132.

Алексеев В.П., Гохман И.И. Антропология азиатской части СССР. М.: Наука, 1984. С. 208.

Багашёв A.Н. Краниологический тип нижнеиртышских хантов. // Обские угры: ханты и манси. М.: Институт этнологии и антропологии РАН, 1991. С. 29-37.

Багашёв А.Н. Краниологический тип пелымских манси. // ВААЭ, 1999. Вып. 2. С. 69-77.

Багашёв А.Н. Палеоантропология Западной Сибири. Новосибирск: Наука, 2000. С. 374.

Берг Л.С. Номогенез, или эволюция на основе закономерностей. //Труды по теории эволюции. Л.: Наука, Ленинградское отделение. 1977. С. 95-311.

Бунак B.B. Основные морфологические черты черепа человека и их эволюция // Русский антропологический журнал, 1922. Т.12, Кн. 1-2. С. 20-56.

Веселовская Е.В., Григорьева О.М., Пестряков А.П., Рассказова А.В. Краниологическая изменчивость населения Восточной и Центральной Европы от средневековья до современности // Вестник Московского университета. Серия XXIII. Антропология. М., 2015. № 1 С. 4-24. 
Гинзбург В.В., Трофимова Т.А. Палеоантропология Средней Азии. М.: Наука, 1972. С. 372.

Дебеи Г.Ф. Антропологические исследования в Камчатской области // Труды северо-восточной экспедиции. М.: Изд-во АН СССР, 1951.

Дрёмов B.A. Краниология среднеобских хантов // Обские угры: ханты и манси. - Ин-т этнологии и антропологии РАН, М., 1991а. С. 10-28.

Дрёмов В.A. Краниометрия // Тюрки таёжного Причулымья. Популяция и этнос. Томск: Издво Том. Ун-та, 1991б. С. 166-169.

Исмагулов О. Население Казахстана от эпохи бронзы до современности. Алма-Ата: Изд-во Наука. Казахская ССР, 1970. С. 240.

Ким А.Р. Материалы к краниологии кызыльцев // Этнокультурные явления в Западной Сибири. Томск: Изд-во Том. Ун-та, 1978а. С. 208-216.

Ким А.P. Материалы к краниологии телеутов // Вопросы археологии и этнографии Сибири. Томск: Изд-во Том. Ун-та, 1984. С. 180-195.

Ким А.P. Материалы к краниологии шорцев и кумандинцев // Западная Сибирь в эпоху средневековья. Томск: Изд-во Том. Ун-та, 1978б. С.151-163.

Миклашевская Н.Н. Краниология киргизов. // Труды Киргизской археолого-этнографической экспедиции, 1959. Т. II. С. 266-294.

Пестряков А.П. Хронологическая изменчивость тотальных размеров и формы мозгового черепа как показатель единства морфологической эволюции человечества. // Расы и расизм. История и современность. М.: Наука, 1991. С.29-59.

Пестряков А.П. Расы человека в краниологической классификации населения тропического пояса. //Современная антропология и генетика и проблема рас у человека. М., 1995. С. 43-90.

Пестряков А.П., Григорьева О.М. Краниологическая дифференциация современного населения. //Расы и народы. Ежегодник, Вып. 30. М.: Наука, 2004. С. 86-131.

Плохинский Н.А. Биометрия. Новосибирск: изд-во СО АН СССР, 1961.

Розов Н.С. Материалы по краниологии чулымцев и селькупов // ТИЭ, 1956. Т. 33. С. 340-373.

Томтосова Л.Ф. Новые материалы по краниологии современных якутов // Сборник МАЭ, 1980. T. XXXVI. C. 121-129.

Чебоксаров Н.Н. Основные направления расовой дифференциации в Восточной Азии // ТИЭ, нов. сер., М., 1947. Т. II. С. 24-83.

Чебоксаров Н.Н. Основные принципы антропологических классификаций // Происхождение человека и древнейшее расселение человечества. ТИЭ, нов. сер., М., 1951. Т.16. С. 231-322.

Pestriakov Aleksander P., Olga M.Grigoryeva, and Yulia V. Pelenitsyna

DOI: $10.33876 / 2311-0546 / 2021-54-2 / 274-291$

\section{Craniometric differentiation of the large Mongoloid race. Part 1. Northern Mongoloids}

52 modern cranial samples of northern Mongoloids from Western and Eastern Siberia, the Far East, Central Asia and Kazakhstan were studied (based on the data from published sources). These groups are usually referred to as "continental Mongoloids" according to N. $N$. Cheboksarov classification. The groups were compared using 11 metric traits describing the size and shape of the skull. The studied samples represent one of the three previously identified world craniotypes, Golarktids. Golarktids have medium-long and wide crania of average size. The cluster analysis revealed three clusters of almost equal size; significant differences in three of the eleven traits were found between the clusters. The first cluster (18 samples) is the most different from the typical appearance of the Golarktids and represents the chronologically earliest stage of Golarktids' evolutionary development. The other two clusters are represented by the larger-headed and smaller-headed variants of typical eastern Golarktids. 
Keywords: neurocranium, cranial samples, craniotypes, cranial sphericity, evolutionary changes

For citation: Pestriakov Aleksander P., Olga M.Grigoryeva, and Yulia V.Pelenitsyna. 2021. Craniometric differentiation of the large Mongoloid race. Part 1. Northern Mongoloids. Herald of Anthropology (Vestnik Antropologii) 2 (54): 274-291.

\section{Author Info:}

Pestriakov, Aleksander P. - PhD in hist., Institute of Ethnology and Anthropology, RAS (Moscow, Leninsky Pr. 32-a). E-mail: labrecon@yandex.ru

Grigorieva, Olga M. - PhD in biol., Institute of Ethnology and Anthropology, RAS (Moscow, Leninsky Pr. 32-a). E-mail: labrecon@yandex.ru

Pelenitsyna, Yulia V. - student of M.V. Lomonosov Moscow state University (Moscow, Kolmogorova street, 1). E-mail: j.pelenitsyna@gmail.com

Funding: The research is published as part of the Research Plan of the Institute of Ethnology and Anthropology (Russian Academy of Sciences, Moscow), "The evolutionary continuum of the genus Homo", Subtopic "Anthropology of Ancient and Modern Populations"

\section{References}

Alekseev, V.P. 1960a. Kraniologiia khakasov v sviazi s voprosami ikh proiskhozhdeniia [Craniology of the Khakas in connection with questions of their origin]. Trudy Kirgizskoi arkheologo-etnograficheskoi ekspeditsii IV: 269-364.

Alekseev, V.P. 1960b. Materialy k paleoantropologii zapadnoi Tuvy [Materials for the paleoanthropology of Western Tuva]. Trudy Tuvinskoi kompleksnoi arkheologo-etnograficheskoi ekspeditsii. V. I: 284-316.

Alekseev, V.P. 1960. K kraniologii tofalarov [To the craniology of Tofalars]. Voprosy antropologii 5: 122-132.

Alekseev, V.P., and I.I. Gokhman. 1984. Antropologiia aziatskoi chasti SSSR. [Anthropology of the Asian part of the USSR], 208. Moscow: Nauka.

Bagashev, A.N. 1991. Kraniologicheskii tip nizhneirtyshskikh khantov [Craniological type of the Lower Irtysh Khanty]. Obskie ugry: khanty i mansi: 29-37.

Bagashev, A.N. 1999. Kraniologicheskii tip pelymskikh mansi [Craniological type of the Pelym Mansi]. VAAE 2: 69-77.

Bagashev, A.N. 2000. Paleoantropologiia Zapadnoi Sibiri. [Paleoanthropology of Western Siberia] Novosibirsk: Nauka.

Berg, L.S. 1977. Nomogenez, ili evoliutsiia na osnove zakonomernostei. [Nomogenesis, or evolution based on regularities]. Trudy po teorii evoliutsii: 95-311. L.: Nauka, Leningradskoe otdelenie

Bunak, V.V. 1922. Osnovnye morfologicheskie cherty cherepa cheloveka i ikh evoliutsiia [The main morphological features of the human skull and their evolution]. Russkii antropologicheskii zhurnal 12 (1-2): 20-56.

Veselovskaia, E.V., O.M. Grigor'eva, A.P. Pestriakov, and A.V. Rasskazova. 2015. Kraniologicheskaia izmenchivost' naseleniia Vostochnoi i Tsentral'noi Evropy ot srednevekov'ia do sovremennosti. [Craniological variability of the population of Eastern and Central Europe from the Middle Ages to the present.]. Vestnik Moskovskogo universiteta. Seriia XXIII. Antropologiia 1: 4-24.

Ginzburg, V.V. 1972. Trofimova T.A. Paleoantropologiia Srednei Azii. [Paleoanthropology of Central Asia]. Moscow: Nauka. 
Debets, G.F. 1951. Antropologicheskie issledovaniia v Kamchatskoi oblasti. [Anthropological research in the Kamchatka region]. Trudy severo-vostochnoi ekspeditsii. Moscow: Izd-vo AN SSSR.

Dremov, V.A. 1991a. Kraniologiia sredneobskikh khantov [Craniology of the Middle Ob Khants]. Obskie ugry: khanty i mansi: 10-28. Moscow: In-t etnologii i antropologii RAN

Dremov, V.A. 1991b. Kraniometriia. [Craniometry]. Tiurki taezhnogo Prichulym'ia. Populiatsiia i etnos, 66-169. Tomsk: Izd-vo Tom. Un-ta.

Ismagulov, O. 1970. Naselenie Kazakhstana ot epokhi bronzy do sovremennosti. [The population of Kazakhstan from the Bronze Age to the present] Alma-Ata: Izd-vo Nauka. Kazakhskaia SSR.

Kim, A.R. 1978a. Materialy k kraniologii kyzyl'tsev [Materials for the kraniology of the Kyzyls]. Etnokul'turnye iavleniia v Zapadnoi Sibiri, 208-216. Tomsk: Izd-vo Tom. Un-ta.

Kim, A.R. 1984. Materialy k kraniologii teleutov [Materials for the craniology of teleutes]. Voprosy arkheologii i etnografii Sibiri, 180-195. Tomsk: Izd-vo Tom. Un-ta.

Kim, A.R. 1978b. Materialy k kraniologii shortsev i kumandintsev [Materials for the craniology of the Shors and Kumandins]. Zapadnaia Sibir'v epokhu srednevekov'ia, 151-163. Tomsk: Izd-vo Tom. Un-ta.

Miklashevskaia, N.N. 1959. Kraniologiia kirgizov. [Craniology of the Kyrgyz.]. Trudy Kirgizskoi arkheologo-etnograficheskoi ekspeditsii II: 266-294.

Pestriakov, A.P. 1991. Khronologicheskaia izmenchivost' total'nykh razmerov i formy mozgovogo cherepa kak pokazatel' edinstva morfologicheskoi evoliutsii chelovechestva. [Chronological variability of the total size and shape of the brain skull as an indicator of the unity of the morphological evolution of mankind]. Rasy i rasizm. Istoriia i sovremennost', 29-59. Moscow: Nauka.

Pestriakov, A.P. 1995. Rasy cheloveka v kraniologicheskoi klassifikatsii naseleniia tropicheskogo poiasa [Human races in the craniological classification of the tropical population]. Sovremennaia antropologiia i genetika i problema ras u cheloveka, 43-90. Moscow.

Pestriakov, A.P., and O.M. Grigor'eva. 2004. Kraniologicheskaia differentsiatsiia sovremennogo naseleniia [Craniological differentiation of the modern population]. Rasy i narody. Ezhegodnik 30, 86-131. Moscow: Nauka

Plokhinskii, N.A. 1961. Biometriia. [Biometrics] Novosibirsk: izd-vo SO AN SSSR.

Rozov, N.S. 1956. Materialy po kraniologii chulymtsev i sel'kupov [Materials on craniology of Chulym and Selkup]. TIE 33: 340-373.

Tomtosova, L.F. 1980. Novye materialy po kraniologii sovremennykh iakutov [New materials on the craniology of modern Yakuts]. Sbornik MAE XXXVI: 121-129.

Cheboksarov, N.N. 1947. Osnovnye napravleniia rasovoi differentsiatsii v Vostochnoi Azii [Основные направления расовой дифференциации в Восточной Азии]. TIE, nov. ser. II: 24-83.

Cheboksarov, N.N. 1951. Osnovnye printsipy antropologicheskikh klassifikatsii [Basic principles of anthropological classifications]. Proiskhozhdenie cheloveka i drevneishee rasselenie chelovechestva. TIE, nov. ser. 16: 231-322. 